\title{
Microsatellite-Based Analysis of Genetic Diversity and Population Structure of Rainbow Trout (Oncorhynchus mykiss) Cultured in Ukraine
}

\author{
Olena Bielikova ${ }^{1, *} \mathbb{D}^{\infty}$, Serhii Tarasjuk ${ }^{1}$, Antonina Mruk $^{1}$, Olga Zaloilo ${ }^{1}$, Alexander \\ Didenko ${ }^{1}$
}

${ }^{1}$ Institute of Fisheries of the National Academy of Sciences of Ukraine, 03164, Kyiv-164, Obukhivska St, 135, Ukraine.

\section{Article History}

Received September 22, 2020

Accepted December 23, 2020

First Online December 25, 2020

Corresponding Author

Tel.: +380507727747

E-mail: belikova.e.y@gmail.com

\section{Keywords}

Rainbow Trout (O. mykiss)

Microsatellite Loci

Genetic Structure

Polymorphism

\begin{abstract}
The genetic structure of rainbow trout farmed in Ukraine were characterized based on microsatellite loci. The selected set of SSR-markers (Simple-sequence repeatsmarkers) had a high degree of polymorphism that allowed determining the specificity of each local stock (average PIC value $=0.785 \pm 0.034$ ). The microsatellite analysis of rainbow trout from the studied stocks showed a high level of genetic diversity ( $\mathrm{uHe}=0.825 \pm 0.030, \mathrm{PIC}=0.785 \pm 0.034, \mathrm{l}=1.836 \pm 0.127$ ). The level of allelic diversity of the selected loci was high, where the average number of alleles per locus was 7.833 , the effective number of alleles per locus was 5.687. The range of amplicon sizes of the studied loci and private alleles for each local group was determined. The cluster analysis showed the presence of three clusters. The range of genetic variability was presented in the graphical interpretation of the principal coordinates analysis (PCoA). Based on unbiased genetic distances, the Kharkiv and Transcarpathian local stocks were found to be the closest, while the Chernivtsi stock was the most distant from them.
\end{abstract}

\section{Introduction}

The rainbow trout (Oncorhynchus mykiss) is one of the most widespread cultured species in the world (Hrytsyniak, Hrynzhevskyi, Tretiak, Kiva, \& Mruk, 2008; Stanković, Crivelli, \& Snoj, 2015). Due to its biological plasticity, rapid weight gain, delicious taste and dietary properties, this fish is very attractive to consumers and manufacturers and its faming is commercially profitable (Hrytsyniak et al., 2008). This species, native to North America was worldwide introduced since the end of the 19th century (Stanković et al., 2015). Rainbow trout cultivation in Ukrainian aquaculture began in 1894 in Pushcha-Voditsa near Kyiv (Titarev, 1980; Hrynzhevskyi et al., 2006) during the period of pan-European introduction (Hrytsyniak et al., 2008). In recent years, about two thousand tons of trout have been produced annually at Ukrainian trout farms (Mruk, 2020).
Compared to other European countries, this is not a high amount; however, due to the creation of highly industrial trout farms, the production amounts of this valuable species in the country are increasing (Terterian, Terterian, \& Kolos, 2011). Currently in Ukraine, there are about 50 large and small trout farms, 10 of which have an annual production of approximately 50 tons of fish and more (Mruk, 2020). Today, there are capacities to grow about 20,000 tons of rainbow trout and char using the existing production base in Ukraine. However, this is possible with the creation of national projects to support the owners of private trout farms. Several studies have been carried on by Ukrainian scientists devoted to the improvement of technologies for the cultivation of salmonids in the conditions of industrial farms, taking into account the specifics of natural conditions in Ukraine (Mruk, Terteryan, Didenko, \& Khandozhivska, 2013; Haloyan, Mruk, Terteryan \& 
Kucheruk, 2017; Mendryhsora, Kurynenko, \& Mruk, 2017). The development of new cultivation approaches with the use of modern methods of population genetic for the assessment of local stocks is aimed at improving the state of trout breeding, as well as at adopting practices of rational management of this type of aquaculture.

There are varieties of rainbow trout in different countries, which represent a wide range of variability in terms of fish-breeding, biological and genetic characteristics (Stanković et al., 2015). Therefore, today an important task is to study the genetic structure and diversity of local stocks of a given species in order to establish the phylogenetic origin using modern tools of molecular genetic analysis.

The knowledge gained from the population genetic analysis of aquatic genetic resources (AqGR) is essential for the management and conservation of biological diversity (Kuciński et al., 2015; Coates, Byrne, M., \& Moritz, 2018) both in natural populations and in aquaculture (FAO, 2018). Modern methods of molecular biology allow obtaining a better characterization of aquatic genetic resources of aquaculture, which is of practical importance for maintaining its stable state. A prerequisite for determining the genetic potential of brood stocks is to study the peculiarities of the intraspecific organization of their genetic structures. This will allow monitoring changes in the gene pool of fish stocks and controlling the level of biodiversity.

FAO's 2019 State of the World's Genetic Resources report (FAO, 2019) indicates that among a number of modern molecular genetic markers along with SNPmarkers, microsatellite loci (SSR) are one of the most proper and convenient for research. Variations in these codominant and selectively neutral DNA markers are used as an indicator of genetic variation (Silverstein, Rexroad, \& King, 2004). Microsatellite loci are widely used to assess the genetic structure of rainbow trout in a number of researchers in different countries, allowing to provide a comparative analysis of the biodiversity of this species (Fishback, Danzmann, \& Ferguson, 2000; Silverstein et al., 2004; Johnson, Rexroad, Hallerman, Vallejo, \& Palti, 2007; Yousefian et al., 2012; Allen, Ferguson, \& Danzmann, 2013; Ceyhun \& Ciltas, 2013; Barat et al., 2015; Abadía-Cardoso et al., 2016; Artamonova, Yankovskaia, Holod, \& Makhrov, 2016; Faccenda, Lunelli, Gandolfi, \& Bozzi, 2018). Microsatellite analysis allows determining allelic diversity and heterozygosity, which are ones of the main primary indicators of polymorphism in the genetic structure of populations (Chistiakov, Hellemans, \& Volckaert, 2006).

An important aspect in the formation of replacement broodstocks is the preservation of their genetic diversity in order to avoid inbreeding. In the practice of fish farming, there are several ways to renew the biodiversity of broodstocks like for example by using individuals from natural populations, where the level of biodiversity is higher, and by genetic control. Rainbow trout do not reproduce in natural conditions in Ukraine as in most countries in Western and central Europe (Stanković et al., 2015; Lyach, 2020). To date, scientists have not reached a consensus to answer the question "why rainbow trout populations do not reproduce in the natural condition across much of Europe" (Stanković et al., 2015). In Ukraine, natural reproduction was not recorded maybe because of human impact on natural and ecological complexes (over-fishing without complying with the basic rules of fish protection, hydraulic engineering, local water pollution) (Ustych, Scherbak, \& Mruk, 2017). Therefore, its occurrence in natural watercourses in Ukraine is due exclusively to uncontrolled escapes from fish farms or to fish stocking for sport fishing. So, the main source for gene pool renewal in trout farms of Ukraine is the genetic material of already existing formed stock. In this regard, the knowledge on the features of the genetic structure of local stocks is an important and pressing task.

Therefore, the aim of our work was to analyze the microsatellite sequences of nuclear DNA of rainbow trout for assessing its genetic diversity in aquaculture of Ukraine.

\section{Materials \& Methods}

\section{Sampling}

The materials for the study were local stocks from three trout farms of Ukraine. These trout farms are located in three regions of Ukraine located in three different temperate-climate ecotones: Forest-steppe, Kharkiv oblast (Novaya Vodolaga, $n=35$ ), Carpathian, Chernivtsi oblast (Berehomet, $n=21$ ), and Carpathian Mountains, Transcarpathian oblast (Turya Polyana, $\mathrm{n}=27$ ) (Figure1).

These farms use a full-cycle system of fish rearing with on-site egg production that facilitates genetic control, while the majority of other trout farms in Ukraine import fertilized eggs from abroad. The studied local farms differ in culture technologies. Kharkiv and Chernivtsi local stocks are cultured in recirculation aquaculture systems (RAS), while the Transcarpathian stock is cultured using the classic technology with water supply from a natural source (river).

Blood of age-3 rainbow trout were used as biological samples for microsatellite analysis. Samples were collected in accordance with the provisions recommended by the European Convention for the Protection of Vertebrate Animals used for research and other scientific purposes (Strasbourg, 1986) ETS No.123. Blood from the caudal vein was taken using a sterile syringe with heparin (25 IU per $1 \mathrm{ml}$ of blood). Samples were transported in refrigerators at $4^{\circ} \mathrm{C}$. The blood was stored at $-20^{\circ} \mathrm{C}$ until DNA extraction.

Total DNA was isolated according to the method recommended in the commercial DNA-Go kit (BioLabTech LTD). The concentration and purity of the obtained DNA were determined by a biophotometer 


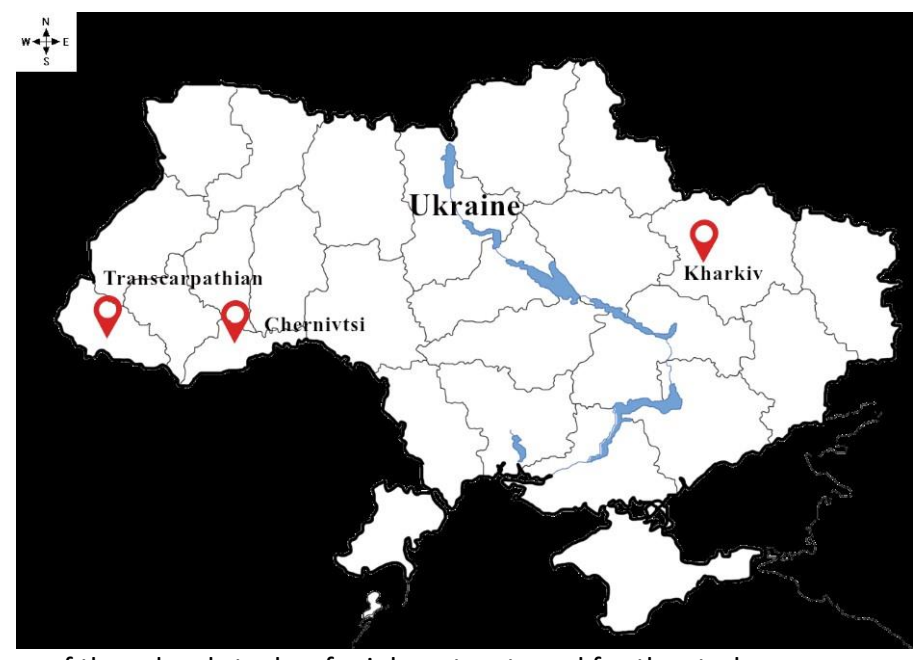

Figure 1. Geographical locations of three local stocks of rainbow trout used for the study.

(Eppendorf, Germany). The ratio of absorption at 260 and $280 \mathrm{~nm}$ (A $260 / 280$ ) was used to assess the quality of the isolated DNA. Samples with A 260 / 280 values higher than 1.75 were used for further analysis.

\section{Microsatellite Analysis}

SSR primers shown in Table 1 were used for analysis. Polymerase chain reaction (PCR) was carried out in a Thermo scientific thermocycler (Arktik Thermal Cycler) using the Thermo Scientific DreamTaq Green PCR Master Mix (2X) under the following conditions: initial DNA denaturation at $94^{\circ} \mathrm{C}$ for 5-10 min (depending on the protocol for each type of primer) the following 30 35 cycles: DNA denaturation at $94^{\circ} \mathrm{C}-30 \mathrm{sec}$, primer annealing at $58^{\circ} \mathrm{C}-30 \mathrm{sec}$, chain synthesis at $72^{\circ} \mathrm{C}-30$ sec; final extension at $72^{\circ} \mathrm{C}$ for $5-10 \mathrm{~min}$.

Amplicons were separated on a $3 \%$ agarose gel with ethidium bromide in $1 \times$ TAE buffer. Foregrams were registered in UV light. The Thermo Scientific pUC19 DNA/Mspl (Hpall) Marker was chosen as a fragment length marker.

\section{Statistical Analysis}

Amplicon analysis was performed in Totallab v.2.01 and Genalex 6.5 (Peakall \& Smouse, 2006, 2012). The polymorphic information content (PIC) was calculated using the formulas generally accepted for codominant markers (Nagy et al., 2012). Analysis of Molecular Variance (AMOVA) was performed using Genalex 6.5. Principal Coordinates Analysis (PCoA) (Jombart, Pontier, \& Dufour, 2009) was performed using genetic distance data for 6 microsatellite markers in Genalex.

The STRUCTURE program (Pritchard, Stephens, \& Donnelly, 2000; Falush, Stephens, M., \& Pritchard, 2003) was used for cluster analysis by the Monte Carlo Markov Chain Scheme (MCMC) algorithm for Bayesian statistics. At the initial stage, the number of assumed clusters $K$ ranged from 1 to 10 with Length of Burnin Period10000, Number of MCMC Reps after Burnin - 50000 with 20 iterations for each cluster. STRUCTURE HARVESTER (Earl \& von Holdt, 2011) was used to determine the most likely number of clusters by the $\Delta \mathrm{K}$ method of Evanno, Regnaut, and Goudet (2005). After that, a secondary set

Table 1. Characterization of microsatellite loci selected for the study

\begin{tabular}{|c|c|c|c|c|c|c|c|c|}
\hline \multirow[b]{2}{*}{ Locus } & \multirow[b]{2}{*}{$\begin{array}{l}\text { Repeat } \\
\text { motif }\end{array}$} & \multirow{2}{*}{$\begin{array}{c}\text { Genbank } \\
\text { accession } \\
\text { number }\end{array}$} & \multirow[b]{2}{*}{ Marker sequence $\left(5^{\prime} \rightarrow 3^{\prime}\right)$} & \multicolumn{4}{|c|}{ PCR conditions } & \multirow[b]{2}{*}{ Reference } \\
\hline & & & & D & AT & $E$ & Cycles & \\
\hline OMM & \multirow{2}{*}{$(A G)_{22}$} & \multirow{2}{*}{ AF352737 } & F:GCGAGGAAGAGAAAGTAGTAG & & \multirow{11}{*}{$\begin{array}{l}58^{\circ} \mathrm{C} 30 \\
\text { sec }\end{array}$} & \multirow{11}{*}{$\begin{array}{l}72^{\circ} \mathrm{C} \\
30 \mathrm{sec}\end{array}$} & \multirow{6}{*}{35} & \multirow{6}{*}{$\begin{array}{l}\text { Rexroad et } \\
\text { al. (2002) }\end{array}$} \\
\hline 1032 & & & R:CCCATCTTCTCTCTGATTATG & & & & & \\
\hline OMM & \multirow[b]{2}{*}{$(\mathrm{GATA})_{9}$} & \multirow[b]{2}{*}{ AF352748 } & F:GGCTGACCAGAGAAAGACTAGT & & & & & \\
\hline 1077 & & & TC R:TGTTACGGTGTCTGACATGC & & & & & \\
\hline OMM & & & F:CTACAGGCCAACACTACAATC & & & & & \\
\hline 1088 & (GA) & Af352/5/ & R:CTATAAAGGGAATAGGCACCT & & & & & \\
\hline Str 15 & $(\mathrm{GT})_{13}$ & $\begin{array}{l}\text { AB001058 } \\
(\mathrm{MST}-15) *\end{array}$ & $\begin{array}{c}\text { F:TGCAGGCAGACGGATCAGGC } \\
\text { R:AATCCTCTACGTAAGGGATTTGC }\end{array}$ & $\begin{array}{c}94^{\circ} \mathrm{C} \\
30 \mathrm{sec}\end{array}$ & & & \multirow{5}{*}{30} & \multirow{5}{*}{$\begin{array}{l}\text { Estoup et } \\
\text { al. (1993) }\end{array}$} \\
\hline Str 60 & $(\mathrm{CT})_{13} \mathrm{AC}$ & AB001057 & F:CGGTGTGCTTGTCAGGTTTC & & & & & \\
\hline \multirow{3}{*}{ Str 73} & \multirow{3}{*}{$\begin{array}{c}\mathrm{CA}(\mathrm{CT})_{3} \\
(\mathrm{GT}) \\
{ }_{13} \mathrm{TTATC} \\
\mathrm{T}(\mathrm{GT})_{3}\end{array}$} & $(\mathrm{MST}-60) *$ & R:GTCAAGTCAGCAAGCCTCAC & & & & & \\
\hline & & AB001056 & F:CCTGGAGATCCTCCAGCAGGA & & & & & \\
\hline & & $(\mathrm{MST}-73) *$ & R:CTATTCTGCTTGTAACTAGACCTA & & & & & \\
\hline
\end{tabular}

Notes: *, Sequences registered in GenBank according to the name used in the reference (Presa \& Guyomard, 1996); F, forward primer's sequence; $R$, reverse primer's sequence; $D$, denaturation; $A T$, annealing temperature; $E$, extension. 
was analyzed for the number of clusters from 2 to 4 , Length of Burnin Period - 500000, Number of MCMC Reps after Burnin - 750000 with 20 iterations for each cluster. CLUMPAK (Kopelman, Mayzel, Jakobsson, Rosenberg, \& Mayrose, 2015) was used to average the iterations of each $\mathrm{K}$ value and to establish the probability of assigning each individual to the initial cluster (using a consensus membership probability, q-value). Graphical interpretation of the obtained results was performed in STRUCTURE PLOT (Ramasamy, Ramasamy, Bindroo, \& Naik, 2014).

Unbiased genetic distances and identity were calculated according to Nei formulae (Nei, 1978), which are used in cases of a small number (up to 50) individuals from each studied population. The MEGA X package (Kumar, Stecher, Li, Knyaz\& Tamura, 2018) was used to build an unrooted dendrogram using the method of unweighted paired average (UPGMA) (Nei, 1996).

\section{Results}

The microsatellite analysis of the genetic structure of local rainbow trout stocks from three Ukrainian fish farms showed that six of the selected SSR loci (OMM 1032, OMM1077, OMM 1088, Str 15, Str 60, Str 73) were polymorphic (Table 2). The number of alleles for all loci varied from 4 (Str 73) to 10 (Str 15), with an average value of 7.833 . The average value of the effective number of alleles per locus was 5.687. A high Shannon index was recorded for all studied loci, while the average value was $1.836 \pm 0.127$. These SSR loci showed a high level of polymorphism PIC $=0.785 \pm 0.034$. The probability of identity (PI) was in the range of 0.04-0.06 for the studied microsatellite loci, with the exception of the locus Str 73 (0.16). Str 73 was the least informative for the selected panel. Looking at the Fsт at marker level, the average genetic differentiation per locus was 0.137 $(P=0.001)$. Among the studied loci, the largest differences of Fst values were observed for the locus Str 73 ( $\left.F_{S T}>0.25\right)$.

The established amplicon ranges for microsatellite loci are specific for the studied Ukrainian rainbow trout stocks (Figure 2). The locus OMM 1088 showed the smallest discrepancy in amplicon ranges among the three local stocks. The narrowest range of alleles was observed at the locus Str 73.

Each of the three studied Ukrainian rainbow trout groups had specific amplicon ranges and allele frequencies for six microsatellite loci (Table 3). Only the locus OMM 1088 had an allele that was found with a high frequency in each of the three groups (125 bp). At the same time, the frequencies of private alleles for each stock were determined and it was found that the Chernivtsi local group had the largest number of private alleles (9). A slightly lower number of private alleles (7) was recorded in rainbow trout of the Transcarpathian local stock. The smallest number of private alleles was found in the Kharkiv local rainbow trout group.

The average values of the number of alleles per locus ( $\mathrm{Na}$ ), the effective number of alleles per locus $(\mathrm{Ne})$, and the Shannon index (I) in the Chernivtsi ( $\mathrm{Na}=4.667 \pm 0.333 ; \mathrm{Ne}=3.878 \pm 0.315 ; \mathrm{I}=1.423 \pm 0.072$ ), Kharkiv ( $\mathrm{Na}=4.333 \pm 0.667 ; \quad \mathrm{Ne}=3.238 \pm 0.508$; $\mathrm{I}=1.197 \pm 0.198)$ and Transcarpathian ( $\mathrm{Na}=4.888 \pm 0.601$; $\mathrm{Ne}=3.505 \pm 0.529 ; \quad \mathrm{I}=1.335 \pm 0.138) \quad$ groups were approximately at the same level (Table 4). In each group, the PIC value was not lower than 0.5 indicating the informativeness of the marker set for studying the genetic diversity of rainbow trout populations.

The expected unbiased heterozygosity (uHe) for the three groups ranged from 0.658 (Kharkiv) to 0.786 (Chernivtsi) indicating an average level of heterogeneity. In general, for all loci, with the exception of OMM1077, a statistically significant deviation from the HardyWeinberg equation was observed $(P<0.05)$ (Table 4). According to the results of the assessment of molecular variance (AMOVA) for the Ukrainian stocks of rainbow trout, $14 \%$ of the genetic variability was attributable to variability among populations, $86 \%$ - within populations, which confirmed the genetic similarity of the studied populations. According to the results of the PCOA analysis, the first and second coordinates described 11.82 and $10.42 \%$ of allelic variance, respectively (Figure 3).

Table 2. Main parameters of genetic diversity of SSR loci for Ukrainian local stocks of rainbow trout

\begin{tabular}{lcccccccc}
\hline Locus & Allele size $(\mathrm{bp})$ & $\mathrm{Na}$ & $\mathrm{Ne}$ & $\mathrm{I}$ & $\mathrm{uHe}$ & $\mathrm{PIC}$ & $\mathrm{PI}$ & $\mathrm{F}_{\mathrm{ST}}(p$-level) \\
\hline OMM 1032 & $200-262$ & 9 & 6.719 & 2.014 & 0.867 & 0.834 & 0.04 & $0.146(0.001)$ \\
OMM1077 & $215-296$ & 9 & 5.386 & 1.901 & 0.830 & 0.793 & 0.06 & $0.077(0.008)$ \\
OMM 1088 & $99-147$ & 7 & 5.360 & 1.795 & 0.829 & 0.789 & 0.06 & $-0.005(0.520)$ \\
Str 15 & $230-319$ & 10 & 7.042 & 2.095 & 0.875 & 0.842 & 0.04 & $0.088(0.002)$ \\
Str 60 & $114-150$ & 8 & 6.627 & 1.971 & 0.866 & 0.831 & 0.04 & $0.219(0.001)$ \\
Str 73 & $128-148$ & 4 & 2.988 & 1.238 & 0.681 & 0.618 & 0.16 & $0.288(0.001)$ \\
\hline Mean & - & 7.833 & 5.687 & 1.836 & 0.825 & 0.785 & - & - \\
SE & - & 0.872 & 0.613 & 0.127 & 0.030 & 0.034 & - & - \\
\hline
\end{tabular}

Notes: Na, Number of alleles per locus; Ne, Effective number of alleles per locus; I, Shannon information index; uHe, expected unbiased heterozygosity; PIC, polymorphic information content; PI, probability of identity; FST, fixation index (results of locus-bylocus AMOVA analysis); p-level, probability value $\mathrm{P}($ rand $>=$ data); $\mathrm{SE}$, standard error of the mean. 
Figure 2. Amplicon ranges by microsatellite loci for three studied rainbow trout groups.

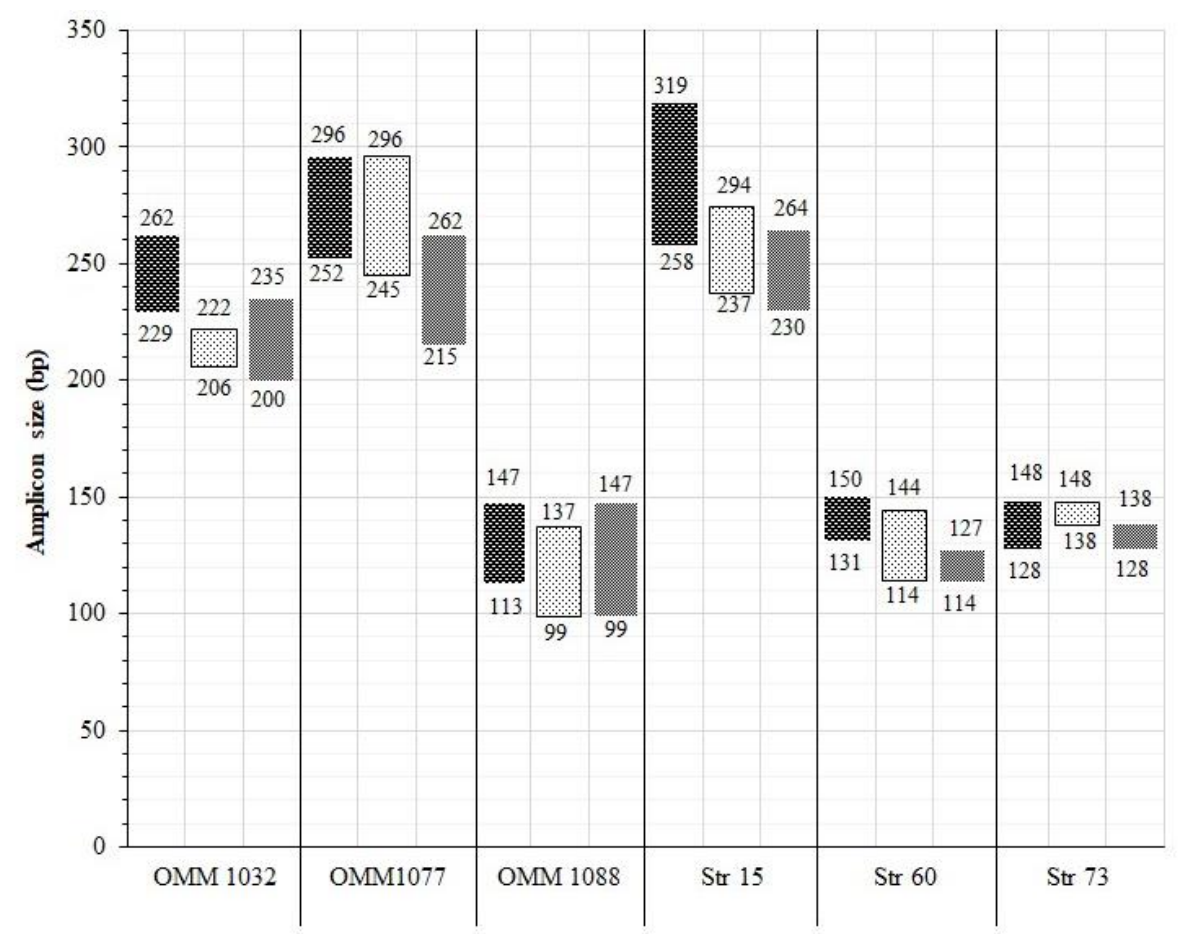

Chernivtsi $⿴$ Kharkiv $\square$ Transcarpathian

Table 3. Frequency of alleles distribution at six microsatellite loci

\begin{tabular}{|c|c|c|c|c|c|c|c|c|c|c|}
\hline \multicolumn{11}{|l|}{ Locus OMM 1032} \\
\hline Allele & 200 & 206 & 215 & 222 & 229 & 235 & 242 & 253 & 262 & \\
\hline Chernivtsi & 0.000 & 0.000 & 0.000 & 0.000 & 0.125 & 0.000 & 0.125 & 0.500 & 0.250 & \\
\hline Kharkiv & 0.000 & 0.300 & 0.300 & 0.400 & 0.000 & 0.000 & 0.000 & 0.000 & 0.000 & \\
\hline $\begin{array}{l}\text { Transcarpathian } \\
\text { Locus OMM1077 }\end{array}$ & 0.278 & 0.111 & 0.222 & 0.222 & 0.111 & 0.056 & 0.000 & 0.000 & 0.000 & \\
\hline Allele & 215 & 225 & 245 & 252 & 262 & 270 & 276 & 285 & 296 & \\
\hline Chernivtsi & 0.000 & 0.000 & 0.000 & 0.063 & 0.188 & 0.188 & 0.250 & 0.063 & 0.250 & \\
\hline Kharkiv & 0.000 & 0.000 & 0.400 & 0.050 & 0.150 & 0.000 & 0.200 & 0.100 & 0.100 & \\
\hline $\begin{array}{l}\text { Transcarpathian } \\
\text { Locus OMM } 1088\end{array}$ & 0.125 & 0.063 & 0.563 & 0.063 & 0.188 & 0.000 & 0.000 & 0.000 & 0.000 & \\
\hline Allele & 99 & 105 & 113 & 118 & 125 & 137 & 147 & & & \\
\hline Chernivtsi & 0.000 & 0.000 & 0.125 & 0.125 & 0.250 & 0.250 & 0.250 & & & \\
\hline Kharkiv & 0.050 & 0.150 & 0.100 & 0.300 & 0.200 & 0.200 & 0.000 & & & \\
\hline $\begin{array}{l}\text { Transcarpathian } \\
\text { Locus Str } 15\end{array}$ & 0.056 & 0.222 & 0.056 & 0.000 & 0.444 & 0.167 & 0.056 & & & \\
\hline Allele & 230 & 237 & 242 & 250 & 258 & 264 & 274 & 292 & 305 & 319 \\
\hline Chernivtsi & 0.000 & 0.000 & 0.000 & 0.000 & 0.143 & 0.000 & 0.000 & 0.286 & 0.143 & 0.429 \\
\hline Kharkiv & 0.000 & 0.350 & 0.200 & 0.350 & 0.000 & 0.050 & 0.050 & 0.000 & 0.000 & 0.000 \\
\hline $\begin{array}{l}\text { Transcarpathian } \\
\text { Locus Str } 60\end{array}$ & 0.222 & 0.222 & 0.167 & 0.222 & 0.111 & 0.056 & 0.000 & 0.000 & 0.000 & 0.000 \\
\hline Allele & 114 & 122 & 127 & 131 & 135 & 140 & 144 & 150 & & \\
\hline Chernivtsi & 0.000 & 0.000 & 0.000 & 0.125 & 0.125 & 0.375 & 0.250 & 0.125 & & \\
\hline Kharkiv & 0.150 & 0.000 & 0.000 & 0.350 & 0.450 & 0.000 & 0.050 & 0.000 & & \\
\hline $\begin{array}{l}\text { Transcarpathian } \\
\text { Locus Str } 73\end{array}$ & 0.125 & 0.250 & 0.625 & 0.000 & 0.000 & 0.000 & 0.000 & 0.000 & & \\
\hline Allele & 128 & 134 & 138 & 148 & & & & & & \\
\hline Chernivtsi & 0.333 & 0.167 & 0.167 & 0.333 & & & & & & \\
\hline Kharkiv & 0.000 & 0.000 & 0.100 & 0.900 & & & & & & \\
\hline Transcarpathian & 0.333 & 0.500 & 0.167 & 0.000 & & & & & & \\
\hline
\end{tabular}

Notes: Frequencies of private alleles for each stock are underlined. 
Table 4. Parameters of genetic diversity of rainbow trout (O. mykiss) groups

\begin{tabular}{|c|c|c|c|c|c|c|c|c|}
\hline Locus & $\mathrm{Na}$ & $\mathrm{Ne}$ & 1 & PIC & $\mathrm{PI}$ & $\mathrm{uHe}$ & Prob & PHW \\
\hline \multicolumn{9}{|l|}{ Chernivtsi } \\
\hline OMM 1032 & 4 & 2.909 & 1.213 & 0.6050 & 0.17 & 0.700 & 0.001 & $* * *$ \\
\hline OMM1077 & 6 & 4.923 & 1.667 & 0.7659 & 0.07 & 0.850 & 0.190 & ns \\
\hline OMM 1088 & 5 & 4.571 & 1.560 & 0.7456 & 0.08 & 0.833 & 0.000 & $* * *$ \\
\hline Str 15 & 4 & 3.267 & 1.277 & 0.6414 & 0.15 & 0.747 & 0.002 & $* *$ \\
\hline Str 60 & 5 & 4.000 & 1.494 & 0.7119 & 0.10 & 0.800 & 0.000 & $* * *$ \\
\hline Str 73 & 4 & 3.600 & 1.330 & 0.6713 & 0.13 & 0.788 & 0.006 & $* *$ \\
\hline Mean & 4.667 & 3.878 & 1.423 & 0.690 & - & 0.786 & - & - \\
\hline SE & 0.333 & 0.315 & 0.072 & 0.025 & - & 0.023 & - & - \\
\hline \multicolumn{9}{|l|}{ Kharkiv } \\
\hline OMM 1032 & 3 & 2.941 & 1.089 & 0.627 & 0.19 & 0.695 & 0.000 & $* * *$ \\
\hline OMM1077 & 6 & 4.082 & 1.583 & 0.768 & 0.09 & 0.795 & 0.133 & ns \\
\hline OMM 1088 & 6 & 4.878 & 1.670 & 0.793 & 0.07 & 0.837 & 0.000 & $* * *$ \\
\hline Str 15 & 5 & 3.448 & 1.356 & 0.815 & 0.14 & 0.747 & 0.026 & $*$ \\
\hline Str 60 & 4 & 2.857 & 1.161 & 0.740 & 0.19 & 0.684 & 0.034 & $*$ \\
\hline Str 73 & 2 & 1.220 & 0.325 & 0.619 & 0.69 & 0.189 & 0.002 & $* *$ \\
\hline Mean & 4.333 & 3.238 & 1.197 & 0.727 & - & 0.658 & - & - \\
\hline SE & 0.667 & 0.508 & 0.198 & 0.034 & - & 0.097 & - & - \\
\hline \multicolumn{9}{|c|}{ Transcarpathian } \\
\hline OMM 1032 & 6 & 4.909 & 1.673 & 0.7659 & 0.07 & 0.843 & 0.002 & $* *$ \\
\hline OMM1077 & 5 & 2.667 & 1.244 & 0.5860 & 0.18 & 0.667 & 0.097 & ns \\
\hline OMM 1088 & 6 & 3.522 & 1.475 & 0.6777 & 0.12 & 0.758 & 0.006 & $* *$ \\
\hline Str 15 & 6 & 5.226 & 1.706 & 0.7803 & 0.06 & 0.856 & 0.001 & $* *$ \\
\hline Str 60 & 3 & 2.133 & 0.900 & 0.4683 & 0.28 & 0.567 & 0.001 & $* *$ \\
\hline Str 73 & 3 & 2.571 & 1.011 & 0.5355 & 0.23 & 0.667 & 0.007 & $* *$ \\
\hline Mean & 4.833 & 3.505 & 1.335 & 0.6356 & - & 0.726 & - & - \\
\hline SE & 0.601 & 0.529 & 0.138 & 0.052 & - & 0.046 & - & - \\
\hline
\end{tabular}

Notes: Prob -PHW, Hardy-Weinberg probability test: ${ }^{*} \mathrm{P}<0.05,{ }^{* *} \mathrm{P}<0.01,{ }^{* * *} \mathrm{P}<0.001$, n.s. $=$ nonsignificant deviation.

Principal Coordinates (1 vs 2)

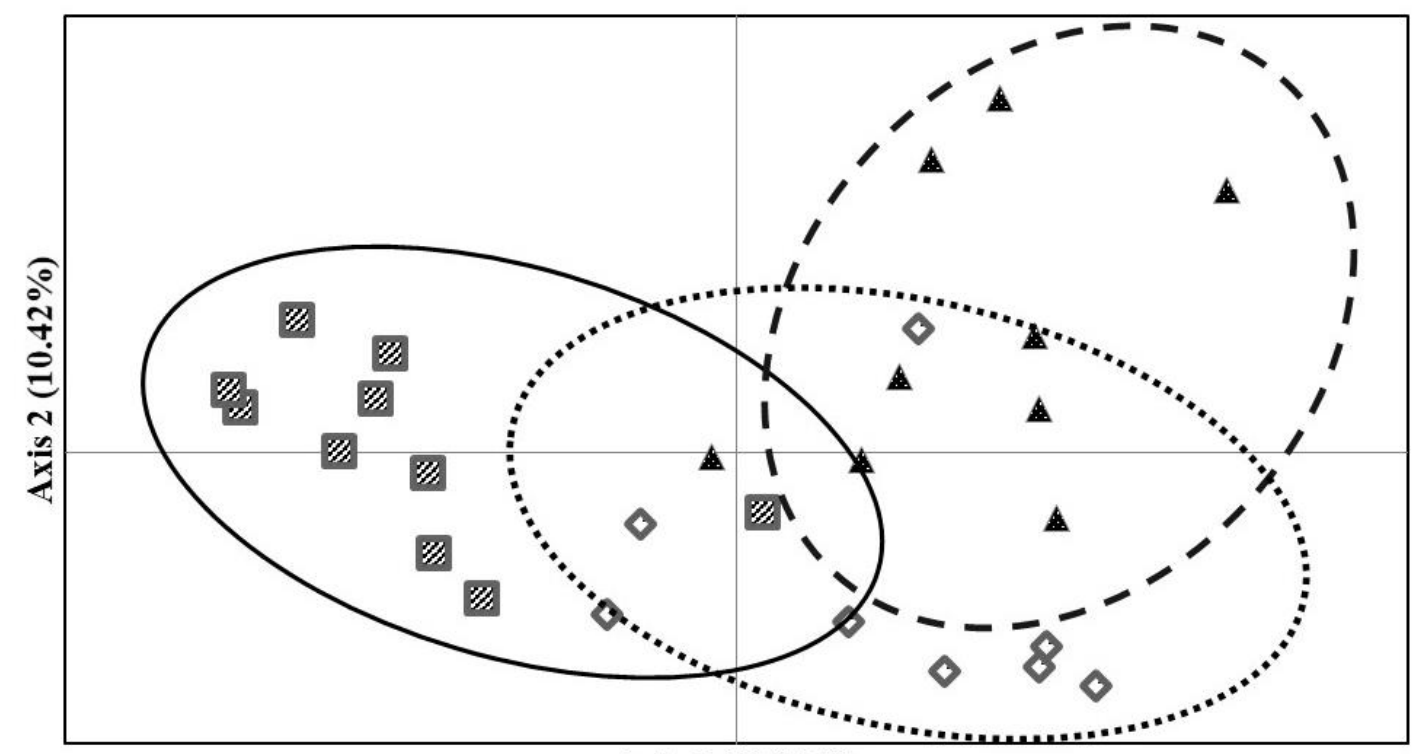

- Chernivtsi

Q Kharkiv

A Transcarpathian

Axis 1 (11.82\%)

Figure 3. Principal component Analysis (PCOA) of the studies local stocks of rainbow trout. 
According to $\Delta \mathrm{K}$, the most probable number of clusters was determined as $\mathrm{K}=3$ (Figure 4). The cluster analysis results allowed building a barplot, which showed the genetic structure, boundaries and subdivisions of local rainbow trout stocks (Figure 5).

The largest unbiased genetic identity was recorded between the Kharkiv and Transcarpathian local stocks, while the lowest one was between the Transcarpathian and Chernivtsi groups of ranbow trout (Table 5). The phylogenetic relationships among the studied local rainbow trout stocks were presented in a UPGMA dendrogram (Figure 6 ) based on Nei's unbiased genetic distances (1978) (Table 5).

\section{Discussion}

Analysis of the genetic structure of local stocks of cultured rainbow trout was carried out using six SSR markers of different origins. Markers OMM 1032, 1077, 1088 (Rexroad, Coleman, Hershberger, \& Killefer, 2002) were developed based on DNA of O. mykiss (Kamloop strain), while primers Str 15, 60, 73 (Estoup, Presa, Krieg, Vaiman, \& Guyomard., 1993) were created from the DNA sequence of the brown trout Salmo trutta. Flanking regions of microsatellite loci were found to persist among closely related species (Presa \& Guyomard, 1996; Artamonova et al., 2016). These SSR loci occur in genomes of several salmonids and are polymorphic making them possible to be used for interspecific comparisons and phylogenetic reconstructions (Presa \& Guyomard, 1996). For example, microsatellite loci OMM $(1032,1077,1088)$ were used in the molecular genetic analysis of the Danube salmon (Hucho hucho) (Kuciński et al., 2015) and taimen (Hucho taimen) (Kuang, Tong, Xu, Yin, \& Sun, 2009), where these markers were highly polymorphic for the studied fish groups. The primers of the Str group $(15,60$ 73) demonstrated high informativeness in studies on the genetic structure of rainbow trout populations (Estoup et al., 1993; Presa \& Guyomard, 1996) and Atlantic salmon (Estoup et al., 1993; Presa \& Guyomard, 1996). This suggests the advisability of the use of a selected set of microsatellite loci for other closely related fish species.

Quite often, studies carried out on rainbow trout (Fishback et al., 2000; Guyomard et al., 2006; Johnson et al., 2007; Allen et al., 2013; Faccenda et al., 2018) use the OMM 1088 locus, which is in the linkage group RT16. Such interest in this marker may be due to the significant level of association of the marker or linkage group with the spawning period (Fishback et al., 2000; Allen et al., 2013). Johnson et al. (2007) showed that the OMM 1088 locus had a high polymorphism index $(P I C=0.79)$ in a study of a rainbow trout broodstock. In our studies, the value of the polymorphic information content was very similar and ranged from 0.6777 to 0.793. Our studies on three local stocks of rainbow trout demonstrated a high informativeness of Str loci $(15,60$, 73) (PIC ranged from 0.618 to 0.842 ). The six microsatellite loci, which we have selected, were highly informative in the analysis of the genetic structure as evidenced by high numbers of alleles per locus, the value of the polymorphic information content ( $\mathrm{PIC}>0.5$ ) and the probability of identity.

Also, and importantly, amplification of this marker set can be carried out at the same primer annealing temperature. These facts allow reducing the costs and time of the analysis and forming multiplex systems later, and as a consequence, this will speed up the monitoring of populations of various fish species using molecular genetic markers.

Our studies demonstrated the features of the gene pool of local Ukrainian rainbow trout stocks. The

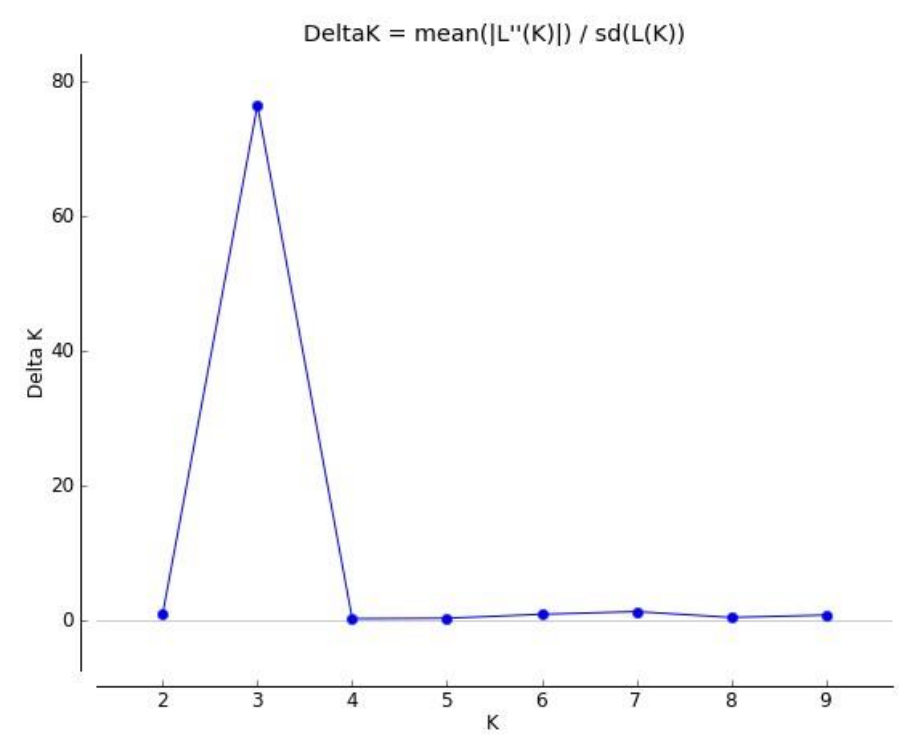

Figure 4. Graphical display of the determination of the most probable number of clusters $(K)$ in the Structure Harvester program. 


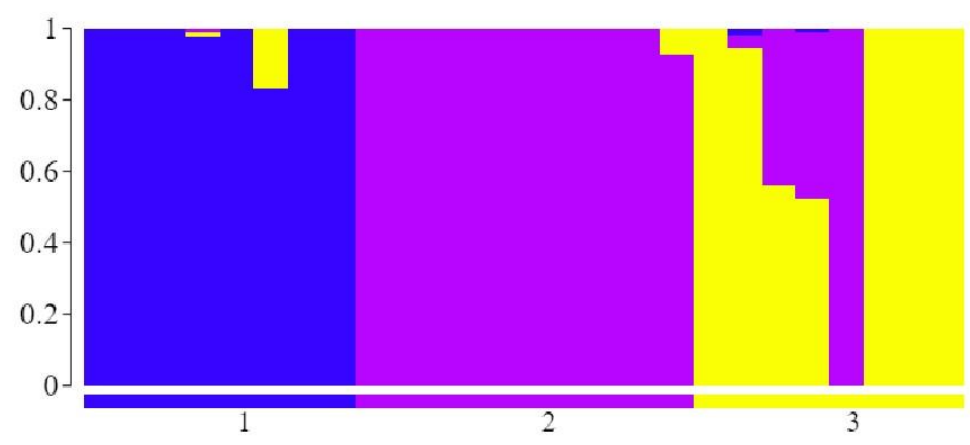

Figure 5. Results of the cluster analysis of local stocks of Ukrainian rainbow trout for six SSR loci using Structure 2.3.4 with K=3: vertically - the proportions of allele frequencies of the corresponding cluster (posterior probability), horizontally - local stock numbers: 1 - Chernivtsi; 2 - Kharkiv; 3- Transcarpathian.

Table 5. Pairwise Population Matrix of Nei Unbiased Genetic Distance (under the diagonal) i Nei Unbiased Genetic Identity (above the diagonal)

\begin{tabular}{llll}
\hline & Chernivtsi & Kharkiv & Transcarpathian \\
\hline Chernivtsi & - & 0.426 & 0.320 \\
Kharkiv & 0.852 & - & 0.455 \\
Transcarpathian & 1.139 & 0.787 & - \\
\hline
\end{tabular}

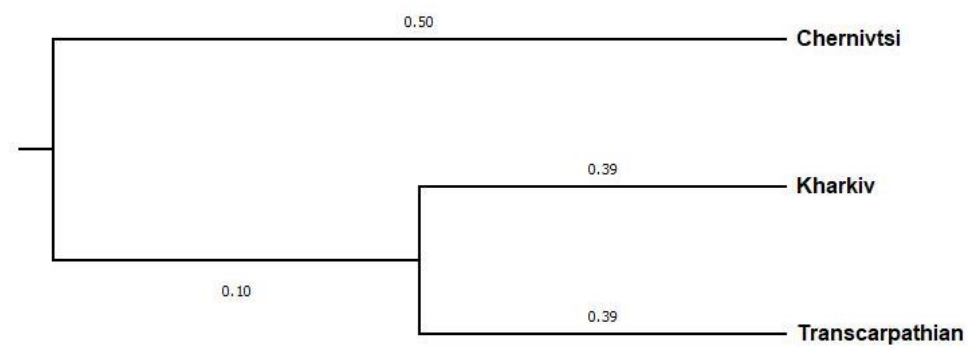

Figure 6. UPGMA dendrogram of genetic relationships among 3 local stocks of rainbow trout using unbiased genetic distance based on 6 microsatellite loci.

number and frequency of alleles in different groups were determined, that is one of the measures to determine the diversity of the genetic structure. The allele range and frequency as well as the presence of private alleles in each local stock are often used to determine the differences among fish broodstocks (Yousefian et al., 2012; Kucinski et al., 2015; Artamonova et al., 2016). Faccenda et al. (2018) used the OMM1088 marker in their studies on the rainbow trout stocks in Trentino (Italy). The number of alleles per locus was higher than in our studies and amounted to 12 , while the $F_{S T}$ index was 0.065 that correlated with our values (FST 0.06). Such a difference in the number of alleles per locus observed in the study of Faccenda et al. (2018) is probably due to a large number of the studied farms and, consequently, to the detection of a higher level of polymorphism at the investigated locus. The studies of Estoup et al. (1993), Presa \& Guyomard (1996) on the rainbow trout determined that the number of alleles per locus was 8 for Str (MST) 15, 5 for Str (MST) 60 , and 3 for Str (MST) 72. Among the loci Str 15, 60, 73, the smallest number of alleles per locus was observed for the locus Str 72. Studies on the brown trout (Ceyhun $\&$ Ciltas, 2013) also showed that the lowest average number of alleles per locus was for the locus Str (MST)73 (2.0) among the selected marker set.

When comparing the generalized parameters of genetic variability among Ukrainian stocks of rainbow trout with the literature, certain common features and differences can be identified. For the locus OMM 1032, Ukrainian local stocks have amplicons with heavier molecular weight in comparison with the data of Rexroad et al. (2002), since slow migration amplicons were 262 and 222 bp, respectively. However, the size of the "light" alleles (200 bp) and the number of alleles per locus were the same. For the locus OMM 1077 a larger number of alleles per locus and an extension of the molecular weight range were found. However, as for the locus OMM 1088, the Ukrainian stocks had only seven alleles per locus compared to twelve alleles detected in the study of Rexroad et al. (2002), and a shift in the molecular weight range: 99-147 bp and 113-170 bp, respectively.

A sufficiently high level of genetic diversity for six microsatellite loci was determined for the studied samples of rainbow trout, since the Shannon index was more than 1.5, which is considered high for SSR markers (Galinskaya, Shchepetov, \& Lysenkov, 2019). The least 
genetically diverse was the Kharkiv group (1.197 \pm 0.198$)$, while the most diverse was the Chernivtsi group (1.423 \pm 0.072$)$.

The recorded deviation from the Hardy-Weinberg equilibrium is expected for small isolated populations. In this case, it is recommended to measure the genetic differentiation for population genetic analysis (Evanno et al., 2005; Hauser, Seamons, Dauer, Naish, \& Quinn, 2006; Latch, Dharmarajan, Glaubitz, \& Rhodes, 2006). To characterize the rainbow trout gene pool, we used the Fst coefficient, which reflected the proportion of the total genetic diversity distributed among subpopulations ( $F_{S T}=0.137 ; P=0.001$ ). However, low Fst values according to Hedrick (2000) can be obtained with modern hypervariable markers that are characterized by many alleles.

The Principal Coordinates Analysis (PCoA), which was based on the analysis of genetic distances calculated using the AMOVA algorithm, reflected the variability range in local stocks of Ukrainian rainbow trout. However, the overlapping regions in the three groups show their genetic similarity.

Based on the values of Unbiased Genetic Distance and Unbiased Genetic Identity, the Kharkiv and Transcarpathian local stocks were shown to be the most genetically close by six studied microsatellite loci. This may indicate that the genetic material used for breeding at these trout farms was historically of the same origin. In our case, molecular methods are a tool that clarifies the issue of the origin and differentiation of stocks, because the rainbow trout has been imported repeatedly from Europe since the time of its panEuropean introduction, and in most cases, this was done spontaneously. The stocks were formed by the method of mass selection (Hrynzhevskyi et al., 2006).

Therefore, today most of the owners of trout farms are interested in cooperation with scientists in order to determine the state of the genetic structure of their local stocks, differentiate from other stocks and carry out their certification. The similarity of these two local stocks can also be seen in the barplot obtained from the cluster analysis (Figure 6). This may be due to the fact that more than 15 years ago the replacement broodstock at the Kharkiv farm was created using eggs from the Transcarpathian local stock. The most genetically distant seems to be the Chernivtsi stock.

\section{Conclusion}

The features of the genetic structure of rainbow trout in aquaculture of Ukraine were characterized using microsatellite loci. The selected set of SSR-loci had a high information content and a degree of polymorphism, which made it possible to determine the specificity of each local stock. This provides a basis for the use of these microsatellite loci for the analysis of biodiversity and differentiation of rainbow trout stocks in the conditions of industrial trout farms. The specific amplicon ranges were shown and the allelic diversity for the selected loci was characterized for each local stock. A cluster analysis of the studied local stocks showed the presence of three clusters. The phylogenetic analysis allowed determining the degree of genetic identity and differentiation. Specific overlap of allelic ranges for the analyzed loci, parameters of Nei's genetic identity (1972), and AMOVA test results identified $86 \%$ variability within populations indicating the genetic proximity of the studied local stocks. At the same time, the cluster analysis results, PCoA and the presence of private alleles of each local stock demonstrated the variability and specificity range of the studied groups of rainbow trout. Based on the results of the comparative analysis of the studied rainbow trout stocks, it can be concluded that, despite the similarity in their genetic structures, each group was characterized by specific features that were expressed in the amplicons sizes, frequencies of certain alleles, and the presence of private alleles.

The data on the genetic diversity based on microsatellite loci in rainbow trout reared in aquaculture conditions of Ukraine can be used as a methodological framework for monitoring the state of gene pools, which will provide recommendations for selective-breeding work with the aim of rational management of genetic resources of trout farms.

\section{Ethical Statement}

Samples were collected in accordance with the provisions recommended by the European Convention for the Protection of Vertebrate Animals used for research and other scientific purposes (Strasbourg, 1986) ETS No.123

\section{Funding Information}

The study was supported by the Fund of Fundamental and Applied Research of the National Academy of Agrarian Sciences of Ukraine on the subject 37.00.01.05 F "To study the mechanisms of adaptation of certain valuable fish species using methods of population genetics" (DR №0116U001227) and 33.00.00.19 P "To investigate the genetic variability of rare and endangered species of salmon and sturgeon fish in the water bodies of the Carpathian region and to develop methods for their reproduction" (DR № 0119U100578) in 2016-2020.

\section{Author Contributions}

Conceptualization: $\mathrm{OB}$ and ST, Data Curation: $\mathrm{OB}$, $S T, A M$ and $O Z$, Formal Analysis: $O B, O Z$ and $A D$, Funding Acquisition: ST, Investigation: $\mathrm{OB}$ and $\mathrm{OZ}$, Methodology: $\mathrm{OB}, \mathrm{ST}$ and $\mathrm{AM}$, Project Administration: $\mathrm{OB}$ and $\mathrm{ST}$, Resources: OB, ST, AM and OZ, Software: $O B$ and OZ, Supervision, visualization and writing - original draft: $O B$, $S T, O Z$ and $A D$, Writing-review and editing: $O B, O Z, A M$ and $A D$. 


\section{Conflict of Interest}

The authors have declared no conflict of interest.

\section{Acknowledgments}

We are also grateful to the trout farms for provided materials.

\section{References}

Abadía-Cardoso, A., Pearse, D. E., Jacobson, S., Marshall, J., Dalrymple, D., Kawasaki, F., Garza, J. C. (2016). Population genetic structure and ancestry of steelhead/rainbow trout (Oncorhynchus mykiss) at the extreme southern edge of their range in North America. Conservation Genetics, 17(3), 675-689. https://doi.org/10.1007/s10592-016-0814-9

Allen, M. S., Ferguson, M. M., \& Danzmann, R. G. (2013). Molecular Markers for Variation in Spawning Date in a Hatchery Population of Rainbow Trout (Oncorhynchus mykiss). Marine Biotechnology, 16(3), 289-298. https://doi.org/10.1007/s10126-013-9547-7

Artamonova, V.S Yankovskaia, V.A., Holod, V.M., \& Makhrov, A.A. (2016). Geneticheskaya differentsiatsiya porod raduzhnoy foreli (Parasalmo mykiss). razvodimykh $v$ Rossiyskoy Federatsii [Genetic differentiation of rainbow trout (Parasalmo mykiss) strains bred in the Russian Federation]. Trudy Instituta biologii vnutrennikh vod RAN, 73 (76), 25-45. https://doi.org/10.24411/03203557-2016-10003

Barat, A., Sahoo, P. K., Kumar, R., Mir, J. I., Ali, S., Patiyal, R. S., \& Singh, A. K. (2015). Molecular characterization of rainbow trout, Oncorhynchus mykiss (Walbaum, 1792) stocks in India. Journal of Genetics, 94(S2), 13-18. https://doi.org/10.1007/s12041-015-0483-3

Ceyhun, S. B., \& Ciltas, A. (2013). Determination of Genetic Variations of Five Different Indigenous Trout Species in Turkey (Salmo trutta sp. L.) by Microsatellite Markers. Turkish Journal of Fisheries and Aquatic Sciences, 13(5), 785-793. https://doi.org/10.4194/1303-2712-v13_5_02

Chistiakov, D. A., Hellemans, B., \& Volckaert, F. A. M. (2006). Microsatellites and their genomic distribution, evolution, function and applications: A review with special reference to fish genetics. Aquaculture, 255(1-4), 1-29.

https://doi.org/10.1016/j.aquaculture.2005.11.031

Coates, D. J., Byrne, M., \& Moritz, C. (2018). Genetic Diversity and Conservation Units: Dealing with the SpeciesPopulation Continuum in the Age of Genomics. Frontiers in Ecology and Evolution, 6, 165. https://doi.org/10.3389/fevo.2018.00165

Earl, D. A., \& vonHoldt, B. M. (2011). STRUCTURE HARVESTER: a website and program for visualizing STRUCTURE output and implementing the Evanno method. Conservation Genetics Resources, 4(2), 359-361. https://doi.org/ 10.1007/s12686-011-9548-7

Estoup, A., Presa, P., Krieg, F., Vaiman, D., \& Guyomard, R. (1993). (CT)n and (GT)n microsatellites: a new class of genetic markers for Salmo trutta L. (brown trout). Heredity, 71(5), 488496.https://doi.org/10.1038/hdy.1993.167

Evanno, G., Regnaut, S., \& Goudet, J. (2005). Detecting the number of clusters of individuals using the software structure: a simulation study. Molecular Ecology, 14(8), 2611-2620.

https://doi.org/10.1111/j.1365-294x.2005.02553.x

Faccenda, F., Lunelli, F., Gandolfi, A., \& Bozzi, R. (2018). Microsatellite-Based Genetic Diversity and Admixture History of Rainbow Trout (Oncorhynchus mykiss Walbaum, 1792) Stocks in Trentino (Italy). Turkish Journal of Fisheries and Aquatic Sciences, 18(7), 881-889. https://doi.org/10.4194/1303-2712-v18_7_06

Falush, D., Stephens, M., \& Pritchard, J. K. (2003). Inference of population structure using multilocus genotype data: linked loci and correlated allele frequencies. Genetics, $164,1567-1587$ https://doi.org/10.3410/f.1015548.197423

FAO. (2018). The State of World Fisheries and Aquaculture 2018 - Meeting the sustainable development goals. Retrieved from http://www.fao.org/3/i9540en/i9540en.pdf

FAO. (2019). The State of the World's Aquatic Genetic Resources for Food and Agriculture. FAO Commission on Genetic Resources for Food and Agriculture assessments. Retrieved from http://www.fao.org/3/ca5256en/CA5256EN.pdf

Fishback, A. G., Danzmann, R. G., \& Ferguson, M. M. (2000). Microsatellite allelic heterogeneity among hatchery rainbow trout maturing in different seasons. Journal of Fish Biology, 57(6), 1367-1380.

https://doi.org/10.1111/j.1095-8649.2000.tb02218.x

Galinskaya, T. V., Shchepetov, D. M., \& Lysenkov, S. N. (2019) Predubezhdeniya o mikrosatellitnykh issledovaniyakh i kak im protivostoyat [Prejudices against microsatellite studies and how to resist them]. Genetika, 55(6), 617632. https://doi.org/10.1134/S0016675819060043

Guyomard, R., Mauger, S., Tabet-Canale, K., Martineau, S., Genet, C., Krieg, F., \& Quillet, E. (2006). A Type I and Type II microsatellite linkage map of Rainbow trout (Oncorhynchus mykiss) with presumptive coverage of all chromosome arms. BMC Genomics, 7(1), 302. https://doi.org/10.1186/1471-2164-7-302

Haloyan, L., Mruk, A., Terteryan, L., \& Kucheruk, A. (2017). Productive characteristics of age-3 brood brown trout (Salmo trutta) reared in the conditions industrial aquaculture. Fisheries Science of Ukraine, 1 (39), 64-72. https://doi.org/10.15407/fsu2017.01.064 (In Ukrainian)

Hauser, L., Seamons, T. R., Dauer, M., Naish, K. A., \& Quinn, T. P. (2006). An empirical verification of population assignment methods by marking and parentage data: hatchery and wild steelhead (Oncorhynchus mykiss) in Forks Creek, Washington, USA. Molecular Ecology, 15, 3157-3173.

http://dx.doi.org/10.1111/j.1365-294X.2006.03017.x.

Hedrick, P.W. (2000). Genetics of Populations. Boston, Jonesand Bartlett., 675 pp.

Hrynzhevskyi, M. V., Sherman, I. M., Hrytsyniak, I. I., Vasylets, S. V., Tretiak, O. M., Tomilenko, V. H., ... Mruk, A. I. (2006). Orhanizatsiia selektsiino-pleminnoi roboty $v$ rybnytstvi [Organization of selection and breeding work in fish farming]. Kyiv, Rybka moia, $352 \mathrm{pp}$.

Hrytsyniak, I. I., Hrynzhevskyi, M. V., Tretiak, O. M., Kiva, O.M., \& Mruk A. I. (2008). Fermerske rybnytstvo [Fish farming]. Herb, 560 pp.

Johnson, N. A., Rexroad, C. E., Hallerman, E. M., Vallejo, R. L., \& Palti, Y. (2007). Development and evaluation of a new microsatellite multiplex system for parental allocation and management of rainbow trout (Oncorhynchus 
mykiss) broodstocks. Aquaculture, 266 (1-4), 53-62. https://doi.org/10.1016/j.aquaculture.2007.02.054

Jombart, T., Pontier, D., \& Dufour, A.B. (2009). Genetic markers in the playground of multivariate analysis. Heredity, 102(4), 330-341.

https://doi.org/10.1038/hdy.2008.130

Yousefian, M., Laloei, F., Hedayatifard, M., Bahrekazemi, M., M. javad Tagavi, Irani, M., Azizifar, V., \& Khasaesi, E. (2012). Microsatellite Diversity in Rainbow Trout (Oncorhynchus mykiss) Stocks of Different Origin. Middle-East Journal of Scientific Research, 11 (9), 11961201. https://doi.org/10.5829/idosi.mejsr.2012.11.09.63218

Kopelman, N. M., Mayzel, J., Jakobsson, M., Rosenberg, N. A., \& Mayrose, I. (2015). Clumpak: a program for identifying clustering modes and packaging population structure inferences across K. Molecular Ecology Resources, 15(5), 1179-1191. https://doi.org/10.1111/1755-0998.12387

Kuang, Y.-Y., Tong, G.-X., Xu, W., Yin, J.-S., \& Sun, X.-W. (2009). Analysis of genetic diversity in the endangered Hucho taimen from China. Acta Ecologica Sinica, 29(2), 92-97. https://doi.org/10.1016/j.chnaes.2009.05.002

Kucinski, M., Fopp-Bayat, D., Liszewski, T., Svinger, V. W., Lebeda, I., \& Kolman, R. (2015). Genetic analysis of four European huchen (Hucho hucho Linnaeus, 1758) broodstocks from Poland, Germany, Slovakia, and Ukraine: implication for conservation. Journal of Applied Genetics, 56(4), 469480. https://doi.org/10.1007/s13353-015-0274-9

Kumar, S., Stecher, G., Li, M., Knyaz, C., \& Tamura, K. (2018). MEGA X: Molecular Evolutionary Genetics Analysis across Computing Platforms. Molecular Biology and Evolution, 35(6), 15471549. https://doi.org/10.1093/molbev/msy096

Latch, E. K., Dharmarajan, G., Glaubitz, J. C., \& Rhodes, O. E. (2006). Relative performance of Bayesian clustering software for inferring population substructure and individual assignment at low levels of population differentiation. Conservation Genetics, 7(2), 295-302. http://dx.doi.org/10.1007/s10592-005-9098-1.

Lyach, R. (2020). The effects of fisheries management on harvest rates of native and non-native salmonid fish species. Journal of Applied Ichthyology, 36(3), 298-314. https://doi.org/10.1111/jai.14037

Mendryhsora, P.D., Kurynenko, G.A., \& Mruk, A.I. (2017). Porivnialna kharakterystyka 3-4 richnykh samyts raiduzhnoi foreli vyroshchenykh $v$ umovakh industrialnoho hospodarstva «Sloboda-Banyliv» [Comparative characteristics of age-3-4 rainbow trout females reared in the conditions of the industrial fish farm «Sloboda-Banyliv»]. Scientific Messenger LNUVMB, 19 (79), 117-121.

http://nbuv.gov.ua/UJRN/nvInu_2017_19_79_25

Mruk, A.I. (2020, February 19 - 20). Farmers organizations role in aquaculture: Ukraine experience [Poster presentation]. Conference AquaFarm 2020 “Aquaculture farmers and farmer organizations: promoting good practices to boost responsible aquaculture" Pordenone, Italy. http://www.aquafarm.show/wpcontent/uploads/2018/04/Mruk-Antonina.pdf

Mruk, A., Terteryan, L., Didenko, A., \& Khandozhivska, A. (2013, November 3-7), Reproductive Characteristics of Brown Trout Raised in Conditions of Industrial Aquaculture in Ukraine. Aquaculture Elsevier Conference $\sim$ Las Palmas, Gran Canaria, Spain.

Nagy, S., Poczai, P., Cernák, I., Gorji, A. M., Hegedús, G., \& Taller, J. (2012). PICcalc: An Online Program to Calculate Polymorphic Information Content for Molecular Genetic Studies. Biochemical Genetics, 50(9-10), 670-672. https://doi.org/10.1007/s10528-012-9509-1

Nei, M. (1978). Estimation of average heterozygosity and genetic distance from a small number of individuals. Genetics, 89 (3), 583-590.

Nei, M. (1996). Phylogenetic analysis in molecular evolutionary genetics. Annual Review of Genetics, 30(1), 371-403. https://doi.org/10.1146/annurev.genet.30.1.371

Peakall, R., \& Smouse, P. E. (2006). Genalex 6: genetic analysis in Excel. Population genetic software for teaching and research. Molecular Ecology Notes, 6(1), 288-295. https://doi.org/10.1111/j.1471-8286.2005.01155.x

Peakall, R., \& Smouse, P. E. (2012). GenAlEx 6.5: genetic analysis in Excel. Population genetic software for teaching and research-an update. Bioinformatics, 28(19), 2537-2539.

https://doi.org/10.1093/bioinformatics/bts460

Presa, P., \& Guyomard, R. (1996). Conservation of microsatellites in three species of salmonids. Journal of Fish Biology, 49(6), 1326-1329. https://doi.org/10.1111/j.1095-8649.1996.tb01800.x

Pritchard, J.K., Stephens, M., \& Donnelly, P. (2000). Inference of population structure using multilocus genotype data. Genetics. 155 (2), 945-959.

Ramasamy, R., Ramasamy, S., Bindroo, B., \& Naik, V. (2014). STRUCTURE PLOT: a program for drawing elegant STRUCTURE bar plots in user friendly interface. SpringerPlus, 3(1), 431. https://doi.org/10.1186/21931801-3-431

Rexroad, C. E., Coleman, R. L., Hershberger, W. K., \& Killefer, J. (2002). Rapid communication: Thirty-eight polymorphic microsatellite markers for mapping in rainbow trout. Journal of Animal Science, 80(2), 541-542. https://doi.org/10.2527/2002.802541x

Silverstein, J. T., Rexroad, C. E., \& King, T. L. (2004). Genetic variation measured by microsatellites among three strains of domesticated rainbow trout (Oncorhynchus mykiss, Walbaum). Aquaculture Research, 35(1), 40-48. https://doi.org/10.1111/j.1365-2109.2004.00979.x

Stanković, D., Crivelli, A. J., \& Snoj, A. (2015). Rainbow Trout in Europe: Introduction, Naturalization, and Impacts. Reviews in Fisheries Science \& Aquaculture, 23(1), 39- 